\title{
Improvement of the optical and photocatalytic properties of ZnAl204: 1\% La3+, x\% Pb2+ nanoparticles synthesized by citrate sol-gel route
}

Hichem Filali ( $\square$ hichemfilali5@yahoo.com )

Universite Freres Mentouri Constantine 1 faculté des sciences exactes

Nahman Boukheit

Laboratoire de Thermodynamique et Traitements de Surface des Matériaux, Université Frères Mentouri, Constantine 1, Algérie

\section{Rafika Bouhroum}

Laboratoire des Techniques Innovantes et Préservation de l'Environnement, Université Frères Mentouri Constantine 1, Algérie

\section{Wassila Chekirou}

Laboratoire de Thermodynamique et Traitements de Surface des Matériaux, Université Frères Mentouri, Constantine 1, Algérie

\section{Ahcène Karaali}

Laboratoire de Thermodynamique et Traitements de Surface des Matériaux, Université Frères Mentouri, Constantine 1, Algérie

\section{Research Article}

Keywords: ZnAl204, nanoparticles, Sol-gel, doping, photocatalytic

Posted Date: March 18th, 2021

DOl: https://doi.org/10.21203/rs.3.rs-316386/v1

License: (c) (i) This work is licensed under a Creative Commons Attribution 4.0 International License. Read Full License 
Improvement of the optical and photocatalytic properties of $\mathrm{ZnAl}_{2} \mathrm{O}_{4}$ : $1 \% \mathrm{La}^{3+}, \mathrm{x} \% \mathrm{~Pb}^{2+}$ nanoparticles synthesized by citrate sol-gel route

H. Filali ${ }^{a^{*}}$, N. Boukheit ${ }^{a}$, R. Bouhroum ${ }^{\text {b }}$, W. Chekirou ${ }^{\text {a }}$, A. Karaali ${ }^{\text {a }}$.

${ }^{a}$ Laboratoire de Thermodynamique et Traitements de Surface des Matériaux, Université

Frères Mentouri, Constantine 1, Algérie.

${ }^{b}$ Laboratoire des Techniques Innovantes et Préservation de l'Environnement, Université Frères Mentouri Constantine 1, Algérie.

*hichemfilali5@yahoo.com 


\title{
Improvement of the optical and photocatalytic properties of $\mathrm{ZnAl}_{2} \mathrm{O}_{4}$ : $1 \% \mathrm{La}^{3+}, \mathrm{x} \% \mathrm{~Pb}^{2+}$ nanoparticles synthesized by citrate sol-gel route
}

\begin{abstract}
Samples of pure zinc aluminate $\left(\mathrm{ZnAl}_{2} \mathrm{O}_{4}\right)$ and doped both with lead $\left(\mathrm{Pb}^{2+}\right)$ at different ratios $(0$, $0.5,1,1.5,2$ and $2.5 \% \mathrm{~mol}$ ) and a constant amount of lanthanum (La: $1 \% \mathrm{~mol}$ ), were prepared by the citrate sol-gel technique, and then annealed at $900^{\circ} \mathrm{C}$ for $2 \mathrm{~h}$. In order to study the structural, optical and thermal properties; different characterization methods were used, such as: powder X-ray diffraction (XRD), scanning electron microscope (SEM), energy dispersive X-ray spectroscopy (EDX), differential scanning calorimetry (DSC), TGA, Fourier transform infrared spectroscopy (FTIR) and Raman spectroscopy. The Analyzes by XRD revealed the presence of the cubic single phase $\mathrm{ZnAl}_{2} \mathrm{O}_{4}$ for all samples, with a crystallites size between 19 and $25 \mathrm{~nm}$. These results were confirmed using FTIR, Raman spectroscopy and SEM. Also, photocatalytic study for different samples of $\mathrm{ZnAl}_{2} \mathrm{O}_{4}$ shows that they can be used like as photocatalyst and good adsorbents for degradation of Hexamethyl crystallized violet dye in aqueous solution.
\end{abstract}

Keywords: word; $\mathrm{ZnAl}_{2} \mathrm{O}_{4}$, nanoparticles, Sol-gel, doping, photocatalytic.

\section{Introduction}

Spinel $\mathrm{ZnAl}_{2} \mathrm{O}_{4}$, has a high thermal and chemical stability, a high mechanical strength and a low surface acidity [1, 2], its wide band gap energy (Eg 3.8 eV) [1, 3-7], its particle size, and large surface area, make it a material of choice for a variety of applications, such as heterogeneous catalysis and adsorption of molecules [8]. Also, zinc aluminate has been recently considered as a functional material in host luminescent applications [9]. Moreover, $\mathrm{ZnAl}_{2} \mathrm{O}_{4}$ has been widely employed as a good host phosphor material as a result of uniform particle and narrow size distribution [10]. For effective doping, rare earths or lanthanides are widely used as activators in luminescent materials due to high emission properties [4-7, 11- 12]

On the other hand, adsorption is a technique that consists of fixing the pollutants on the surface of an adsorbent without altering the pollutant. It is very widely used as a refining treatment. Photocatalyst is also aims to eliminate organic micro pollution, but unlike adsorption, its ultimate goal is to degrade or even mineralize organic pollutants. In recent years, zinc aluminate has been largely used as a photocatalyst for degradation of organic pollutants in water such as dyes. In our work also tested it as an adsorbent to remove the HCV dye. The crystal violet dye was considered as a low biodegradable and 
very persistent organic pollutant. Its presence in aquatic environments can be detrimental to animal and plant species as well as to the various microorganisms living in these waters. The absorption of the HCVs is maximal at the wavelength $590 \mathrm{~nm}$. Therefore, in order to assess the effectiveness of the synthesized $\mathrm{ZnAl}_{2} \mathrm{O}_{4}$ powder and even what field it can be used in; the water treatment area was tested as a photocatalysts to purify the water from organic pollutants [9].

It is known that, zinc aluminate has the normal spinel structure and the chemical formula of $\mathrm{AB}_{2} \mathrm{O}_{4}$ in which $\mathrm{Zn}^{2+}(\mathrm{A})$ ions occupy tetrahedral sites and $\mathrm{Al}^{3+}(\mathrm{B})$ ions the octahedral sites. In general, $\mathrm{A}$ and $\mathrm{B}$ cations can reside on both $\mathrm{T}$ and $\mathrm{M}$ sites, thus giving rise to a variable disorder degree, which can be described using the inversion parameter $\mathrm{i}$, defined as the fraction of the $\mathrm{B}$ cations at the $\mathrm{T}$ sites. The inversion parameter can therefore vary from 0 , in the completely normal spinel ${ }^{\mathrm{T}} \mathrm{A}^{\mathrm{M}} \mathrm{B}_{2} \mathrm{O}_{4}$, to 1 , in the completely inverse spinels ${ }^{\mathrm{T}} \mathrm{B}^{\mathrm{M}}(\mathrm{AB}) \mathrm{O}_{4}$; while the value $2 / 3$ is assuming for a completely random (i.e. disordered) cation distribution [17]. Many synthesis methods preparation of $\mathrm{ZnAl}_{2} \mathrm{O}_{4}$ have been reported, such as: hydrothermal [10, 18]; citrate [1, 19, 20], sol-gel [21-22], combustion [13, 23-25], pyrolysis [14, 26], co-precipitation [15, 27- 29] and solvothermal [30-31]. While doping $\mathrm{ZnAl}_{2} \mathrm{O}_{4}$ was carried out with transition metals or rare earths depending on the intended application [6-7, 14, 32].

In this present study, we have used the citrate sol-gel method for preparing samples of pure $\mathrm{ZnAl}_{2} \mathrm{O}_{4}$ and dual doped by a constant concentration of $\mathrm{La}^{3+}(1 \% \mathrm{~mol})$ and $\mathrm{x} \% \mathrm{~mol}$ $\mathrm{Pb}^{2+}$ with_different amounts of Lead $(0,0.5,1,1.5,2$, and $2.5 \% \mathrm{~mol})$. The materials annealed at $900^{\circ} \mathrm{C}$ for $2 \mathrm{~h}$ have been characterized for their structural and optical properties. In addition, we have prepared a sample $\mathrm{ZnAl}_{2} \mathrm{O}_{4}$ containing $50 \%$ by weight of $\mathrm{ZnO}$ in order to better characterize the effectiveness of the two purification methods, notably photocatalysis and adsorption.

\section{Methods and Materials}

\subsection{Synthesis of $\mathrm{ZnAl}_{2} \mathrm{O}_{4}$}

To prepare the $\mathrm{ZnAl}_{2} \mathrm{O}_{4}$ powder, $2.19 \mathrm{~g}$ of Zinc Acetate dihydrate $\left(\mathrm{C}_{4} \mathrm{H}_{6} \mathrm{O}_{4} \mathrm{Zn} .2 \mathrm{H}_{2} \mathrm{O}\right)$ was mixed with $20 \mathrm{ml}$ of distillated water and stirred magnetically for 30 minutes. On the other hand, another solution contains $7.5 \mathrm{~g}$ of Aluminum nitrate nonahydrate (Al $\left.\left(\mathrm{NO}_{3}\right) .9 \mathrm{H}_{2} \mathrm{O}\right)$ and $20 \mathrm{ml}$ of distillated water was prepared with the same preceding method. The two solutions were mixed well using the citric acid $\left(\mathrm{C}_{6} \mathrm{H}_{8} \mathrm{O}_{7}\right)$ as chelating 
agent. Then the resulted mixture was dried on hot plate at $80^{\circ} \mathrm{C}$ during 90 minutes. The doped $\mathrm{ZnAl}_{2} \mathrm{O}_{4}$ solutions were prepared exactly like the pure one. A constant amount of Lanthanum Acetate hydrate $\left(\mathrm{La}\left(\mathrm{CH}_{3} \mathrm{CO}_{2}\right)_{3} \cdot \mathrm{H}_{2} \mathrm{O}\right)(1 \%$ mol $)$ was added in the first solution of Zinc. On the other hand, different amount of Lead (II) Acetate trihydrate $\left(\mathrm{C}_{4} \mathrm{H}_{6} \mathrm{O}_{4} \mathrm{~Pb} .3 \mathrm{H}_{2} \mathrm{O}\right)$ was added to the second solution of Aluminum nitrate $(0,0.5,1,1.5$, 2 and $2.5 \% \mathrm{~mol}$ ). After drying the mixture obtained, it is subjected to a heat treatment at $900^{\circ} \mathrm{C}$ for $2 \mathrm{~h}$ in an oven. Finally, we have seven samples called pure $\mathrm{ZnAl}_{2} \mathrm{O}_{4}, \mathrm{~S} 0$, S1, S2, S3, S4 and S5 respectively.

\subsection{Photocatalytic and adsorption}

To test the reactivity of the two processes on the HCV molecules, a solution containing $\mathrm{HCV}$ with concentrations equal to $5 \mathrm{mg} / \mathrm{l}$ and $0.1 \mathrm{~g}$ for each sample of $\mathrm{ZnAl}_{2} \mathrm{O}_{4}$ powder has prepared. The evolution of HCV was followed as a function of time of contact, by the measurement of the absorption at $590 \mathrm{~nm}$. In photocatalytic activity, a cylindrical Pyrex photo reactor initiated by UV mercury lamp $(350 \mathrm{~W})$ placed in center of a closed enclosure, the solution of $\mathrm{HCV}$ and the catalyst were stirred in the dark for 30 minutes to establish the adsorption-desorption equilibrium. After each appropriate time interval, $5 \mathrm{ml}$ aliquots was sampled and filtered using 0, $22 \mu \mathrm{m}$ membranes filters (S-PAK), to remove the solid phase thus allowing the analyze by spectrophotometer (SHIMADZU, UV-1800).

\subsection{Characterization}

The obtained powder was characterized by $\mathrm{X}$-ray diffraction using $\mathrm{Cu}_{\mathrm{K} \alpha}$ radiation Bruker (D8 Advance) X-ray diffractometer. The structural composition of powders was studied using m-Raman spectrometer (Jobin-Yvon). Optical properties were analyzed using UV-visible spectrophotometer (Shimadzu, UV-1800). The Morphological studies of powders were carried out by Scanning Electron Microscopy (Philips XL30 S-FEG). FT-IR analysis was carried away using $\mathrm{KBr}$ disc technique on a FT-IR spectrometer Bruker IFS66v. EDX measurements have been performed with a Hitachi S-3000N scanning electron microscope and the thermal analysis of dried gel was studied by STA 449 F3 Jupiter®. 


\section{Results and discussions}

\subsection{Powder X-ray diffraction}

Figure 1.a shows the XRD diagrams of pure $\mathrm{ZnAl}_{2} \mathrm{O}_{4}$ and samples S0, S1, S2, S3, S4 and S5. All patterns show the characteristic diffraction peaks corresponding to (111), (220), (311), (400), (331), (422), (511), (440),(620),(533),(642),(731) reflections of cubic $\mathrm{ZnAl}_{2} \mathrm{O}_{4}$ spinel structure (JCPDS No. 05-0669). These results show the existence of traces impurities such as $\mathrm{ZnO}$ on some samples. The degree of crystallinity is calculated from the XRD spectra of the samples:

$$
\mathrm{C}(\%)=\frac{\text { Area of crystalline peaks } * 100}{\text { Area of all peaks }}
$$

, and the results are presented in Table 1.The average size of the crystallites (D) was calculated from the five most intense X-ray diffraction peaks, using Scherrer's formula (1), [7, 16-18].

$$
\mathrm{D}=\frac{0.9 \lambda}{\beta \cos \theta}
$$

Where $\lambda$ is the wavelength of $\mathrm{Cu}-\mathrm{K} \alpha(0.15406 \mathrm{~nm}), \beta$ is the full width at half maximum (FWHM) of the peak and $\theta$ is the Bragg angle. We found average crystallites size between 19 and $25 \mathrm{~nm}$ for S2 and S5, respectively (Table 1). In addition, we noticed a slight shift of the peaks of the S0 sample towards the low angles compared to the pure sample of $\mathrm{ZnAl}_{2} \mathrm{O}_{4}$. This suggested that the increase in lattice parameter is most likely due to the presence of $\mathrm{La}^{3+}$ in $\mathrm{ZnAl}_{2} \mathrm{O}_{4}$ system. Because, the ionic radius of $\mathrm{La}^{3+}(1.04$ A) [27] is greater than those of the tetrahedral $\left(\mathrm{Zn}^{2+}(0.60 \AA \hat{)}), \mathrm{Al}^{3+}(0.39 \AA \hat{)})\right)$ and octahedral $\left(\mathrm{Zn}^{2+}\left(0.74 \AA\right.\right.$, $\left.\mathrm{Al}^{3+}(0.54 \AA \hat{)})\right)$ sites of $\mathrm{ZnAl}_{2} \mathrm{O}_{4}$ system [19]. Similar results have been previous observed in the $\mathrm{ZnAl}_{2} \mathrm{O}_{4}$ doped by Lanthanides elements [11, 14, 18].The most intense (220) and (311) diffraction peaks for all samples are illustrated in figure 1.b. We observe also that when $\mathrm{Pb}^{2+}$ is added up to $1.5 \% \mathrm{~mol}$ to the $\mathrm{S} 0$ sample, the shift of the most intense peaks is towards the large angles, then beyond this percentage of $\mathrm{Pb}^{2+}$, the shift changes by meaning. Although the ionic radius of $\mathrm{Pb}^{2+}$ $(1.23 \AA)$ [32] is greater than those of $\mathrm{Zn}^{2+}$ and $\mathrm{Al}^{3+}$, the Vegard's law is violated up to $1.5 \%$ mol. The lattice parameters (a) for all samples are presented in Table 1. The variation of the lattice parameter of the samples versus of the $\% \mathrm{~Pb}^{2+}$ is represented by figure 1.c, and shows well the parabolic behavior relationship to $\mathrm{Pb}^{2+} \mathrm{mol} \%$. This result 
can be explained by the decrease in the electronic cloud of the outer layer of $\mathrm{Pb}^{2+}$, due to its electronic interactions with a greater number of closer neighbors $\mathrm{Zn}^{2+}$, which makes it smaller than the $\mathrm{Zn}^{2+}$ ion. As the percentage of $\mathrm{Pb}^{2+}$ is increased, the shrinkage must be smaller; therefore, the lattice parameter should be increase. We note a similar phenomenon was observed by S.V. Motlung and al. [33].

\subsection{FTIR spectroscopy}

The fig. 2 represents the IR spectra of the samples pure $\mathrm{ZnAl}_{2} \mathrm{O}_{4}$ and S0, S1, S2, S3, S4 and S5. We observe the same absorption bands in all spectra, such the broad band centered on $3400 \mathrm{~cm}^{-1}$ and the band $1615 \mathrm{~cm}^{-1}$. These are related to the $\mathrm{OH}$ stretching vibration and $\mathrm{H}_{2} \mathrm{O}$ deformation vibration, respectively. Also, the presence of three absorption bands located at 643, (550-565) and $501 \mathrm{~cm}^{-1}$ comes from the stretching and bending modes vibration of octahedral bonds $\left(\mathrm{AlO}_{6}\right)$ [34-36]. These bands are characteristic of the $\mathrm{ZnAl}_{2} \mathrm{O}_{4}$ spinel structure. The sharp absorption band at $2300 \mathrm{~cm}^{-1}$ is due to the stretching vibration mode of $\mathrm{CO}_{2}$. The adsorption of water and carbon dioxide from the atmosphere may be due to the very high specific surface area of these materials [37]. No other impurity phase is detected by FTIR spectra, and is in good agreement with the results obtained by XRD.

\subsection{DSC and TGA}

The behavior of the gel as a function of temperature was studied by continuous heating using simultaneously thermo gravimetric analysis (TGA) and differential scanning calorimetry (DSC). The thermal cycle applied under an atmosphere of neutral nitrogen consists of heating from ambient temperature to $1000{ }^{\circ} \mathrm{C}$ at a speed of $10{ }^{\circ} \mathrm{C} / \mathrm{min}$, followed by holding at this temperature for 10 minutes, and cooling to ambient temperature. The TGA and DSC pattern of pure $\mathrm{ZnAl}_{2} \mathrm{O}_{4}$ is record and depicted in fig. 3 . The TGA and DSC curves of all samples are almost similar. Thermo gravimetric analysis reveals that the thermal decomposition of precursors takes place in four stages (see fig.3.a): The first loss of mass $(\sim 14 \%)$ is observed between room temperature and $210{ }^{\circ} \mathrm{C}$. It probably corresponds to the dehydration of the gel (adsorbed water). A second mass loss $(9 \%)$, starts at $210{ }^{\circ} \mathrm{C}$ and ends at $310^{\circ} \mathrm{C}$ [38]. It can only be attributed to the decomposition of nitrates. The third stage reveals a significant loss of mass ( $37 \%)$ which is mainly due to the combustion of acetates and citric acid. 
Finally, a weak mass loss $(\sim 8 \%)$ which begins at $550{ }^{\circ} \mathrm{C}$ and ends in the vicinity of $1000{ }^{\circ} \mathrm{C}$. This mass loss probably corresponds to the removal of the hydroxyl groups. The total weight loss is approximately $68 \%$ of the initial mass of the precursor at $1000^{\circ} \mathrm{C}$.

On DSC curves during heating, phase changes cause absorption or release of heat, which manifests as an endothermic (exothermic) peak during the reaction. The DSC analysis curve (fig.3.b) shows the existence of several peaks:

- A large peak at $110{ }^{\circ} \mathrm{C}$ corresponding to the evaporation of water

- Two exothermic peaks at 417 and $655^{\circ} \mathrm{C}$, the first can be attributed to the formation of aluminum and zinc hydroxide phases, and the second broad peak is due to the formation of the cubic structure spinel $\mathrm{ZnAl}_{2} \mathrm{O}_{4}$. We have also noticed that the increase in the quantities of $\mathrm{Pb}$ leads to the small displacement of the peaks towards the low temperatures.

\subsection{Raman analysis}

It is well known that Raman spectroscopy is a characterization method to measure the frequencies of the long-wavelength lattice vibrations (phonons). Raman spectroscopy provides a fast and convenient method for detecting small structural changes in materials. On the other hand, according to group theory, $\mathrm{ZnAl}_{2} \mathrm{O}_{4}$ should exhibit five Raman active modes: $A_{1 g}+E_{g}+3 T_{2 g}$ [38]. However, the figure 4 displays Raman spectra of all samples treated at $900^{\circ} \mathrm{C}$ for $2 \mathrm{~h}$. These spectra are similar and reveal the presence of four peaks located at $196,419,512$ and $660 \mathrm{~cm}^{-1}$ and correspond, respectively, to $\mathrm{T}_{2 \mathrm{~g}}$, $\mathrm{E}_{\mathrm{g}}, \mathrm{T}_{2 \mathrm{~g}}$, and $\mathrm{T}_{2 \mathrm{~g}}$ phonon frequencies of $\mathrm{ZnAl}_{2} \mathrm{O}_{4}$ spinel structure [20,38-40]. In addition, peak $T_{2 \mathrm{~g}}$ (3) at $660 \mathrm{~cm}^{-1}$ is most intense and represents the fingerprint of $\mathrm{ZnAl}_{2} \mathrm{O}_{4}$ spinel [17]. Obviously, the peak located at $727 \mathrm{~cm}^{-1}$ corresponding to the active mode $A_{1 g}$ is not observed on our spectra. This peak is attributed to the symmetrical stretching vibration $\mathrm{Al}-\mathrm{O}$ of the $\mathrm{AlO}_{4}$ groups created by the redistribution of certain aluminium ions from the octahedral sites to the tetrahedral sites [41]. Therefore, the $\mathrm{ZnAl}_{2} \mathrm{O}_{4}$ spinel formed in our samples shows very little inversion. Furthermore, the $\mathrm{E}_{\mathrm{g}}$ peak at $419 \mathrm{~cm}^{-1}$ also does not show the asymmetry typical of disordered $\mathrm{ZnAl}_{2} \mathrm{O}_{4}$ spinel as shown in figure 5 [38]. We can conclude that the results obtained by Raman spectroscopy confirm those found by X-ray diffraction. 


\subsection{UV-VIS}

The diffuse reflectance spectra of the samples annealed at $900{ }^{\circ} \mathrm{C}$ for $2 \mathrm{~h}$ in a range of 240 to $800 \mathrm{~nm}$ are presented in figure 6. For all the samples, we observed an absorption band in the UV (220-270 nm) region, which can be attributed to the band-to-band transition of the $\mathrm{AlO} 6$ in $\mathrm{ZnAl}_{2} \mathrm{O}_{4}$ spinel [42-43]. Another absorption band appears at $460 \mathrm{~nm}$ for the S0 sample and which shifts towards low wavelengths up to $1 \% \mathrm{~mol}$ $\mathrm{Pb}^{2+}$, then it takes the reverse path up to $350 \mathrm{~nm}$ (S4 sample), to finally disappear giving a wide band for sample S5. This band arises from the defects absorption within the spinel material. Also, we notice that the absorption edge shifts slightly towards the low energies, with increase of $\% \mathrm{~Pb}^{2+}$ doping. However, in the VIS region from 450 to 720 $\mathrm{nm}$, the reflectance improves with the increase of the doping $\left(\% \mathrm{~mol} \mathrm{~Pb}^{2+}\right)$. The maximum reflectance is obtained for $1 \% \mathrm{~mol} \mathrm{La}^{3+}$ and $0 \% \mathrm{~Pb}^{2+}$ ( $\mathrm{S} 0$ sample). We note, that this improvement of reflectance has been observed also in $\mathrm{Sm}(0.5 \% \mathrm{~mol}): \mathrm{ZnAl}_{2} \mathrm{O}_{4}$ nanomaterials synthesized by vibrational milling [11].

The band gap energy $(\mathrm{Eg})$ of the $\mathrm{ZnAl}_{2} \mathrm{O}_{4}$ samples can be determined from plots of $(\mathrm{K} . \mathrm{h} v)^{\mathrm{n}}$ versus hv shown in figure 7 (with $\mathrm{n}=2$, which is appropriate for a direct band gap material such as $\mathrm{ZnAl}_{2} \mathrm{O}_{4}$ ) using the Tauc relation given in Equation (4)

$$
(\mathrm{K} . \mathrm{h} v)^{2}=\mathrm{C}(\mathrm{h} v-\mathrm{Eg})
$$

Where $\mathrm{K}$ is the Kubelka-Munk function [35] given in equation (5):

$$
\mathrm{K}=(1-\mathrm{R})^{2} /(2 \mathrm{R})=\mathrm{F}(\mathrm{R})
$$

$\mathrm{R}$ is reflectance (\%), $\mathrm{h} v$ is the photon energy, $\mathrm{C}$ is a proportionality constant, and $\mathrm{Eg}$ band gap energy. The determination the intercept on the hv axis by extrapolating the linear part of the plot to $(\mathrm{K} \times \mathrm{h} v)^{2}=0$ as shown in figure 7 , give the band gap energy $\left(E_{\mathrm{G}}\right)$. The values of the obtained optical band gaps are: $3.95 ; 3.85 ; 3.70 ; 3.60 ; 3.48 ; 3.34$ and $3.05 \mathrm{eV}$ for pure $\mathrm{ZnAl}_{2} \mathrm{O}_{4}, \mathrm{~S} 0, \mathrm{~S} 1, \mathrm{~S} 2, \mathrm{~S} 3, \mathrm{~S} 4$ and S5 samples respectively. These results confirm the displacement of the absorption edge towards large wavelengths with the increase of the $\% \mathrm{~Pb}$ as well as the change of the forbidden band of $\mathrm{ZnAl}_{2} \mathrm{O}_{4}$ doped with $\mathrm{Pb}^{2+}$. 


\subsection{Scanning electron microscopy}

The observations of this micrograph allow us to say that the morphology of the grains is irregular (fig.8). It varies from a spheroid shape for small particles to an elongated shape for large particles. The particle size is widely distributed with an average size of around $100 \mathrm{~nm}$. This leads to the conclusion that the crystallites tend to agglomerate in small clusters [44], giving nanoparticles having sizes much larger than those of the crystallites $(25 \mathrm{~nm})$ calculated from Sherrer's formula.

\subsection{EDX}

Figure 9, showing the spectrum of pure $\mathrm{ZnAl}_{2} \mathrm{O}_{4}$, clearly indicates the detection of the elements $(\mathrm{Zn}, \mathrm{Al}$, and $\mathrm{O})$ present in pure zinc titanate. While in fig. 9.b, which represents the spectrum of sample $S 1$, we note, in addition to the matrix elements, the presence of dual doping elements $(\mathrm{La}$ and $\mathrm{Pb}$ ) [45]. We also observe on the other spectra which are not represented here, that the intensity of the lead peak increases when the percentage of the latter increases. The presence of carbon comes from the metallization of the samples.

\subsection{Photocatalytic activity}

As shown in Fig. 10, the degradation of $\mathrm{HCV}$ by direct photolysis requires which may appear in practice too long; this renders the process of little benefit to environmental applications as compared to other methods. For this reason, we examined: (i) adsorption and (ii) photo catalysis. Experimentally, the only difference between the two processes is the absence and presence of ultraviolet radiation in adsorption and photocatalysts respectively.

Figure 11 (a), (b) and (c) compares the results obtained with those of direct photolysis, it is clear that the addition of $\mathrm{ZnAl}_{2} \mathrm{O}_{4}$ powder of different types in the reaction medium considerably accelerates the degradation of the dye. Besides to that the dispersion rate is different compared to the powder used.

Before UV-light irradiation, each suspension of photocatalysts/HCV solutions was continuously stirred in the dark for $30 \mathrm{~min}$ to reach an adsorption-desorption equilibrium. For the entire sample, the adsorption efficiency of $\mathrm{HCV}$ varied between 0 and $30 \%, 45 \%$ and $55 \%$ in $\mathrm{ZnAl}_{2} \mathrm{O}_{4}-\mathrm{ZnO}$, pure $\mathrm{ZnAl}_{2} \mathrm{O}_{4}$ and $\mathrm{S} 5$ respectively. These 
results indicate that the synthesized $\mathrm{ZnAl}_{2} \mathrm{O}_{4}$ is good adsorbent, what encouraged us to continue the study of adsorption.

After 120 min of irradiation, the dye degrades by $75 \%, 70 \%$ and $57 \%$ by $\left(\mathrm{ZnAl}_{2} \mathrm{O}_{4}+\right.$ $\mathrm{ZnO}$ ), S5 and pure $\mathrm{ZnAl}_{2} \mathrm{O}_{4}$, respectively. The difference in dye removal rate depends on the body used. Pure $\mathrm{ZnAl}_{2} \mathrm{O}_{4}$ is the least efficient catalyst. However, the presence of $\mathrm{Pb}$ and $\mathrm{ZnO}$ respectively, in the other two samples $\mathrm{S} 5$ and $\left(\mathrm{ZnAl}_{2} \mathrm{O}_{4}+\mathrm{ZnO}\right)$, makes them more potent.

This is due to the fact that the atoms of lead replace the atoms of $\mathrm{Zn}$ and $\mathrm{Al}$, which creates surface exchanges and an increase in the lattice parameter as well as a decrease in gap energy $(\sim 3 \mathrm{eV})$, making sample S5 more powerful and efficient than pure $\mathrm{ZnAl}_{2} \mathrm{O}_{4}(\mathrm{Eg}=3.9 \mathrm{eV})$. As for $\left(\mathrm{ZnAl}_{2} \mathrm{O}_{4}+\mathrm{ZnO}\right)$, it is the most efficient because of its structure, its wide band gap $(3 \mathrm{eV})$ and its excitonic energy of $60 \mathrm{meV}$; the highest value of all semiconductors [46]. In this study, we observe that the photocatalytic behavior of zinc aluminates strongly depends on the energy of the forbidden band (Eg) [47].

\subsubsection{Discussion photocatalytic Activity}

The photon excitation of $\mathrm{ZnAl}_{2} \mathrm{O}_{4}$ amounts to creating electron-hole pairs, that is, a redox system, by passing the electrons $\left(\mathrm{e}^{-}\right)$from the valence band $(\mathrm{BV})$ to the conduction band (BC) creating a positive hole $\left(\mathrm{h}^{+}\right)$in BV.

The created holes move to the surface of the material where their high oxidizing power manifests itself towards the adsorbed oxidizable species. While the electrons produced act on the reducible adsorbed species. It is accepted that in an aerated environment, the electrons, which have acquired the energy of the conduction band, are captured by the adsorbed oxygen to give superoxide radical ions and a new state of equilibrium being established on the oxide surface [48- 50]. In our case, the electron donors can be $\mathrm{H}_{2} \mathrm{O}$, $\mathrm{OH}^{-}$or the pollutant $\mathrm{HCV}$.

The mechanism of photo catalysis includes the following reactions:

$$
\begin{aligned}
& \mathrm{ZnAl}_{2} \mathrm{O}_{4}(\mathrm{ZnO})+\mathrm{h} v \rightarrow \mathrm{ZnAl}_{2} \mathrm{O}_{4}(\mathrm{ZnO})+\mathrm{h}++\mathrm{e}^{-} \\
& \mathrm{H}_{2} \mathrm{O}+\mathrm{h}^{+} \rightarrow \mathrm{OH}+\mathrm{H}+ \\
& \mathrm{OH}^{-}+\mathrm{h}^{+} \rightarrow \mathrm{OH} \\
& \mathrm{O}_{2}+\mathrm{e}- \rightarrow \mathrm{O}_{2^{-}} \\
& \mathrm{HCV}(\mathrm{P})+\cdot{ }^{\cdot} \mathrm{OH}\left(\mathrm{O}_{2} \cdot{ }^{-}\right) \rightarrow \mathrm{H}_{2} \mathrm{O}+\mathrm{CO}_{2}
\end{aligned}
$$




\subsection{Adsorption Activity}

When the three solutions are stirred in the dark for 30 minutes, the three samples studied prefer adsorption to photo-catalysis. Figure 11. (d) indicates the monitoring of adsorption as a function of contact time (under the same conditions as photocatalysis (temperature, concentration, etc.)), allows to conclude on the one hand that the adsorption is remarkable for three samples and on the other hand that the retention rate is 50,42 and $25 \%$ on $\mathrm{S} 5$, pure $\mathrm{ZnAl}_{2} \mathrm{O}_{4}$ and $\mathrm{ZnAl}_{2} \mathrm{O}_{4}+\mathrm{ZnO}$ after 30 minutes, respectively.

After 150 minutes of contact, the remaining amount of $\mathrm{HCV}$ decreases and the adsorbed amount increases, the dispersion rate was found to be $64 \%, 60 \%$ and $50 \%$ in the presence of $\mathrm{ZnAl}_{2} \mathrm{O}_{4}+\mathrm{ZnO}$, S5 and pure $\mathrm{ZnAl}_{2} \mathrm{O}_{4}$ respectively.

In the case of pure and doped $\mathrm{ZnAl}_{2} \mathrm{O}_{4}$, the curves have two important parts, between [0.30mn] the curve is linear, there is a rapid degradation with a high speed and more important for S5. After 30 minutes of contact, the degradation decreases with a slow and constant speed, and the curves have a flat level.

This is explained by the rapid fixation of the molecules in the first moments, because in addition to the presence of surface pores, there is a great affinity between the molecules of the dye and of the adsorbent. The formation of the kinetic plateau ( $\mathrm{C} / \mathrm{C} 0)$ informs us that all the pores are occupied by molecules of $\mathrm{HCV}$.

Concerning the $\mathrm{ZnAl}_{2} \mathrm{O}_{4}+\mathrm{ZnO}$ sample, the adsorption is slow because from the first moments of contact up to 150 minutes, the HCV molecules slowly bind to the surface because there is a lack of affinity between $\mathrm{ZnO}$ and $\mathrm{HCV}$ molecules. On the other hand, the same isothermal model of Langmuir confirms this adsorption.

We found that the binding rate of HCV molecules is higher for the samples of S5 and pure $\mathrm{ZnAl}_{2} \mathrm{O}_{4}$ than for the sample $\mathrm{ZnAl}_{2} \mathrm{O}_{4}+\mathrm{ZnO}$. The affinity between the adsorbate and the adsorbent and the adsorbents structures strongly influence the binding performance, i.e. the speed fixation of the HCV molecules. in addition, doping with divalent or trivalent ions at the aluminum site can modify the structure of spinel aluminates [51]. Polarization in spinel aluminates is determined by the trivalent aluminum ion at the octahedral site [52 - 55]. 


\section{Conclusion}

The $\mathrm{ZnAl}_{2} \mathrm{O}_{4}: 1 \% \mathrm{La}^{3+}, \mathrm{x} \% \mathrm{~Pb}^{2+}$ powders was successfully prepared by citrate sol-gel technique. The Raman and DRX results confirmed that all samples prepared are consisted of single-phase cubic spinel structure without other impurity phases; in addition the formation of spinel that verified through TGA/DTA analysis. Moreover, the FTIR results confirmed the presence of absorption bands from stretching and bending vibration modes of octahedral bonds (A1O6) which correspond to a formation of normal $\mathrm{ZnAl}_{2} \mathrm{O}_{4}$. Meanwhile, the average value of crystallite size decrease with the increase of $\mathrm{Pb}^{2+}$ doping up to $1 \%$ mol $(19 \mathrm{~nm})$, and then it increases to reach $25 \mathrm{~nm}$ at $2.5 \% \mathrm{~mol}$ $\mathrm{Pb}^{2+}$. Regarding the lattice parameter, we notice that the Vegard's law is violated up to $1.5 \% \mathrm{~mol} \mathrm{~Pb}^{2+}$, i.e. the lattice parameter decreases instead of increasing. On the other hand, UV-Visible spectra indicate that the band gap of the dual doped samples decreased with the increase of $\mathrm{Pb}^{2+}$ content ion concentration. Meanwhile, reflectance spectra revealed that absorption edge of $\mathrm{ZnAl}_{2} \mathrm{O}_{4}$ powders had shifted to lower energy by the addition of $\mathrm{Pb}^{2+}$ content. From the previous results, the presence of the elementary composition for all samples was confirmed through the EDX analysis. Finally, photocatalytic study for different samples of $\mathrm{ZnAl}_{2} \mathrm{O}_{4}$ shows that they can be used like as photocatalysts and good adsorbents for degradation of Hexamethyl crystallized violet dye in aqueous solution.

\section{Acknowledgements}

We, the authors, thank the Autonoma University Spanish Laboratory, especially doctor M.Mansosilvan, for providing all the facilities required to conduct experiments in very good conditions. 


\section{References:}

[1] Battiston S, Rigo C, E. Severo da C, et al. Synthesis of zinc aluminate $\left(\mathrm{ZnAl}_{2} \mathrm{O}_{4}\right)$ spinel and its application as photocatalyst. Materials Research. 2014; 17(3):734738.

[2] Wang S.-F, Sun G.-Z, Fang L.-M, et al. A comparative study of $\mathrm{ZnAl}_{2} \mathrm{O}_{4}$ nanoparticles synthesized from different aluminum salts for use as fluorescence materials, Scientific Reports. 2015; 5(12849).

[3] Shahmirzaee M, Shafiee Afarani M, Arabi AM, et al. In situ crystallization of $\mathrm{ZnAl}_{2} \mathrm{O}_{4} / \mathrm{ZnO}$ nanocomposite on alumina granule for photocatalytic purification of wastewater. Res Chem Intermed. 2016; 43:321-340.

[4] Li X, Zhu Z, Zhao Q, et al. Photocatalytic degradation of gaseous toluene over $\mathrm{ZnAl}_{2} \mathrm{O}_{4}$ prepared by different methods: A comparative study. Journal of Hazardous Materials. 2011; 186(2-3):2089-2096.

[5] Zhang L, Yan J, Zhou M, et al. Fabrication and photocatalytic properties of spheres-in-spheres $\mathrm{ZnO} / \mathrm{ZnAl}_{2} \mathrm{O}_{4}$ composite hollow microspheres, Applied Surface Science 2013; 268:237-245.

[6] Buvaneswari K, Vetha G, Andal V. Green synthesis of $\mathrm{ZnAl}_{2} \mathrm{O}_{4}$ nanoparticles for the degradation of methyl orange dye under visible light. ChemTech. 2015; 8(5):06-09.

[7] Ianoş R, Borcănescu S, Lazău R. Large surface area $\mathrm{ZnAl}_{2} \mathrm{O}_{4}$ powders prepared by a modified combustion technique. Chemical Engineering Journal. 2014; 240:260-263.

[8] Zhao L, Li XY, Zhao J. Fabrication, Characterization and Photocatalytic Capability of $\mathrm{ZnAl}_{2} \mathrm{O}_{4}$ Nanospheres, Advanced Materials Research, 2012; 518523:736-739.

[9] Song $\mathrm{X}$, Zheng $\mathrm{S}$, Zhang $\mathrm{J}$, et al. Synthesis of monodispersed $\mathrm{ZnAl}_{2} \mathrm{O}_{4}$ nanoparticles and their tribology properties as lubricant additives. Materials Research Bulletin. 2012; 47:4305-4310. 
[10] Tsai M-T, Chang Y-S, Huang I-B, et al. Luminescent and structural properties of manganese-doped zinc aluminate spinel nanocrystals. Ceramics International. 2013; 39:3691-3697.

[11] Mekprasarta W, Boonyarattanakalina K. Pecharapaa W, et al. Optical characteristics of samarium doped $\mathrm{ZnAl}_{2} \mathrm{O}_{4}$ nanomaterials synthesized by vibrational milling process. Materials Today: Proceedings. 2018; 5:1412614130.

[12] Dutta DP, Ghildiyal R, Tyagi AK. Luminescent Properties of Doped Zinc Aluminate and Zinc Gallate White Light Emitting Nanophosphors Prepared via Sonochemical Method. Journal of Physical Chemistry C. 2009;113:16954-16961.

[13] Peng C, Guo J, Liu M, et al. Enhanced ethanol sensing properties based on $\mathrm{Sm}_{2} \mathrm{O}_{3}$-doped $\mathrm{ZnO}$, Nanocomposite. RSC Advances. 2014; 4:64093-64098.

[14] Kumar M, Natarajan V, Godbole SV, Synthesis, characterization, photoluminescence and thermally stimulated luminescence investigations of orange red-emitting $\mathrm{Sm}^{3+}$-doped $\mathrm{ZnAl}_{2} \mathrm{O}_{4}$ phosphor. Bull. Mater. Sci. 2014; 37:1205-1214.

[15] Mahajan R, Kumar S, Prakash R, ety al. Synthesis and luminescent properties of $\mathrm{Sm}^{3+}$ doped zinc aluminate phosphor. AIP Conference Proceedings. 2018; 1953:1-4.

[16] Prakash R, Kumar S, Mahajan R, et al. Spectral properties of $\mathrm{Dy}^{3+}$ doped $\mathrm{ZnAl}_{2} \mathrm{O}_{4}$ phosphor, AIP Conference Proceedings. 2018; 1953:1-4.

[17] D'Ippolito V, Andreozzi GB, Bersani D, et al. Raman fingerprint of chromate, aluminate and ferrite spinels. J. Raman Spectrosc. 2015; 46:1255-1264.

[18] Dwibedi D, Murugesan C, Leskes M, et al. Role of annealing temperature on cation ordering in hydrothermally prepared zinc aluminate $\left(\mathrm{ZnAl}_{2} \mathrm{O}_{4}\right)$ spinel. Materials Research Bulletin. 2018; 98:219-224.

[19] Elakkiya V, Sumathi S, Ce and Fe doped gahnite: Cost effective solar reflective pigment for cool coating applications, Journal of Alloys and Compounds. 2020; 820:153174.

[20] Motloung SV, Tshabalala KG, Kroon RE, et al. Effect of $\mathrm{Tb}^{3+}$ concentration on the structure and optical properties of triply doped $\mathrm{ZnAl}_{2} \mathrm{O}_{4}: 1 \% \mathrm{Ce}^{3+}, 1 \% \mathrm{Eu}^{3+}$, $\mathrm{x} \% \mathrm{~Tb}^{3+}$ nano-phosphors synthesized via citrate sol-gel method. Journal of 
Molecular Structure. 2019; 1175:241-252.

[21] Tangcharoen T, T-Thienprasert J, Kongmark C, Effect of calcination temperature on structural and optical properties of $\mathrm{MAl}_{2} \mathrm{O}_{4}(\mathrm{M}=\mathrm{Ni}, \mathrm{Cu}$, $\mathrm{Zn}$ ) aluminate spinel nanoparticles. Journal of Advanced Ceramics. 2019;8 :352-366.

[22] Zhou AP, Zhang D, Gong ZQ, et al. The structure and photoluminescence performances of $\mathrm{Zn}_{\mathrm{x}} \mathrm{Al}_{2} \mathrm{O}_{4}: \mathrm{Cr}^{3+}$ crystals with various annealing temperatures. Optoelectronics and Advanced Materials - Rapid Communications. 2018; 12:588-594.

[23] Singh V, Singh N, Pathak MSet al. Singh, Annealing effects on the luminescence properties of $\mathrm{Ce}$ doped $\mathrm{ZnAl}_{2} \mathrm{O}_{4}$ produced by combustion synthesis. Optik. 2018; 155:285-291.

[24] Mirbagheri SA, Masoudpanah SM, Alamolhoda S. Structural and optical properties of $\mathrm{ZnAl}_{2} \mathrm{O}_{4}$ powders synthesized by solution combustion method: Effects of mixture of fuels. Optik. 2020; 204:164170.

[25] Priya R, Negi A, S. Singla, et al. Luminescent studies of Eu doped $\mathrm{ZnAl}_{2} \mathrm{O}_{4}$ spinels synthesized by low-temperature combustion route. Optik. 2020; 204:164173.

[26] Chenga $\mathrm{Y}$, Suna $\mathrm{K}$, Ge $\mathrm{P}$, Up-conversion luminescence in $\mathrm{Yb}^{3+/} \mathrm{Er}^{3+}$ codoped $\mathrm{ZnGa}_{2} \mathrm{O}_{4}$ and $\mathrm{ZnAl}_{2} \mathrm{O}_{4}$ powder phosphors. Optik. 2018; 170:1-9.

[27] Liu J, Zhou W, Jiang D, et al. Insights into the Doping Effect of Rare-Earth Metal on $\mathrm{ZnAl}_{2} \mathrm{O}_{4}$ Supported PtSn Catalyzed Isobutane Dehydrogenation. Catalysis Today. 2020 doi:10.1016/j.cattod.2020.04.016.

[28] Akika FZ, Benamira M, Lahmar H, et al. Structural and optical properties of $\mathrm{Cu}$-doped $\mathrm{ZnAl}_{2} \mathrm{O}_{4}$ and its application as photocatalyst for $\mathrm{Cr}(\mathrm{VI})$ reduction under sunlight. Surfaces and Interfaces. 2020;18:100406.

[29] Somraksa W, Suwanboon S, Amornpitoksuk P, et al. Physical and Photocatalytic Properties of $\mathrm{CeO}_{2} / \mathrm{ZnO} / \mathrm{ZnAl}_{2} \mathrm{O}_{4}$ Ternary Nanocomposite Prepared by Co-precipitation Method, Mat. Res. 2020; 23(1):e20190627.

[30] Zhang D, Qiu YH, Xie YR, et al. The improvement of structure and photoluminescence properties of $\mathrm{ZnAl}_{2} \mathrm{O}_{4}: \mathrm{Cr}^{3+}$ ceramics synthesized by using 
solvothermal method. Materials and Design. 2017; 115:37-45.

[31] Femila Komahal F, Nagabhushana H, Basavaraj RB, G.P. et al. Solvothermal synthesis and luminescent properties of hierarchical flowerlike $\mathrm{ZnAl}_{2} \mathrm{O}_{4}: \mathrm{Ho}^{3+}$ microstructures. Optical Materials. 2018; 84:536-544.

[32] Singh V, Tiwari MK. UV emitting $\mathrm{Pb}^{2+}$ doped $\mathrm{Ca}_{2} \mathrm{La} 2(\mathrm{SiO} 4)_{6} \mathrm{O}_{2}$ phosphors prepared by sol-gel procedure. Optik. 2020; 206:163600.

[33] Motloung SV, Dejene FB, Swart HC.et al. Effects of Pb2+ions concentration on the structure and PL intensity of $\mathrm{Pb}$-doped $\mathrm{ZnAl}_{2} \mathrm{O}_{4}$ nanocrystals synthesized using sol-gel process. Journal of Sol-Gel Science and Technology. 2014; 70:422427.

[34] Elakkiya V, Sumathi S, Ce and Fe doped gahnite: Cost effective solar reflective pigment for cool coating applications. Journal of Alloys and Compounds. 2020; 820:153174.

[35] Staszak W, Zawadzki M, Okal J. Solvothermal synthesis and characterization of nanosized zinc aluminate spinel used in iso-butane combustion. Journal of Alloys and Compounds. 2010; 492:500-507.

[36] Wu X, Wei Z, Chen X, et al. Effects of Cobalt Doping on the Microstructure and Optical Properties of $\mathrm{ZnAl}_{2} \mathrm{O}_{4}$ Nanoparticles. Russian Journal of Physical Chemistry A. 2017; 91:2651-2656.

[37] Ianos R, Lazau R, Lazau I, et al. Chemical oxidation of residual carbon from $\mathrm{ZnAl}_{2} \mathrm{O}_{4}$ powders prepared by combustion synthesis. Journal of the European Ceramic Society. 2012; 32:1605-1611.

[38] D'Ippolito V, Andreozzi GB, Bosi F, et al. Crystallographic and spectroscopic characterization of a natural Zn-rich spinel approaching the end member gahnite $\left(\mathrm{ZnAl}_{2} \mathrm{O}_{4}\right)$ composition. Mineralogical Magazine. 2013; 77:2941-2953.

[39] Chopelas A, Hofrmeister AM. Vibrational Spectroscopy of Aluminate Spinels at 1 atm and of $\mathrm{MgAl}_{2} \mathrm{O}_{4}$ to Over 200 kbar. Phys Chem Minerals. 1991; 18:279-293.

[40] Fang CM, Loong C-K., de Wijs GA, et al. Phonon spectrum of $\mathrm{ZnAl}_{2} \mathrm{O}_{4}$ spinel from inelastic neutron scattering and first-principles calculations. Physical Review B. 2002; 66.144301.

[41] Cynn H, Sharmaand SK, Cooney TF, et al. High-temperature Raman investigation of order-disorder behavior in the $\mathrm{MgA}_{2} \mathrm{O}_{4}$ spinel. Physical Review 


\section{B. $1992 ; 45: 500-502$.}

[42] Motloung SV, Dejene FB, Swart HC, et al. Effects of $\mathrm{Cr}^{3+}$ mol \% on the structure and optical properties of the $\mathrm{ZnAl}_{2} \mathrm{O}_{4}: \mathrm{Cr}^{3+}$ nanocrystals synthesized using sol-gel process. Ceramics International.2015; 41:6776-6783.

[43] Motloung SV, Dejene FB, Koao LF,et al. Structural and optical studies of $\mathrm{ZnAl}_{2} \mathrm{O}_{4}: \mathrm{x} \% \mathrm{Cu}^{2+}(0<\mathrm{x} \leq 1,25)$ nanophosphors synthesized via citrate sol-gel route. Optical Materials.2017; 64:26-32.

[44] Motloung S.V, Tsega M, Dejene FB, et al. Effect of annealing temperature on structural and optical properties of $\mathrm{ZnAl}_{2} \mathrm{O}_{4}: 1.5 \% \mathrm{~Pb}^{2+}$ nanocrystals synthesized via sol-gel reaction. Journal of Alloys and Compounds. 2016; 677:72-79.

[45] Motloung SV, Dejene FB, Swart HC, et al. Effect of $\mathrm{Zn} /$ citric acid mole fraction on the structure and luminescence properties of the un-doped and $1.5 \% \mathrm{~Pb}^{+2}$ doped $\mathrm{ZnAl}_{2} \mathrm{O}_{4}$ powders synthesized by citrate sol-gel method. Journal of luminescence. $2015 ; 163: 8-16$.

[46] Konan KF, Hartiti B, AKA B, et al. Thevenin, Propriétés structurales et optiques de couches minces d'oxyde de zinc $(\mathrm{ZnO})$ texturées (002) par voie sol-gel via spin-coating. Afrique SCIENCE. 2010; 06:29 - 37.

[47] Tangcharoen T, T-Thienprasert J, Kongmark C. Optical properties and versatile photocatalytic degradation ability of $\mathrm{MAl}_{2} \mathrm{O}_{4}(\mathrm{M}=\mathrm{Ni}, \mathrm{Cu}, \mathrm{Zn})$ aluminate spinel nanoparticles. Journal of Materials Science: Materials in Electronics. 2018;29:8995-9006.

[48] Pramauro E, Vincenti M, Augugliaro V, et al. Photocatalyticdegradation of Monuron in aqueoustitaniumdioxide dispersions. Environmental Science \&Technology. 1993;27:1790-1795.

[49] Ollis DF, Pelizzetti E, Serpone N, Photolysis Fundamentals and Applications, eds. John. Wiley and sons (Toronto, Canada). Chapter. 1989;18:603-637.

[50] Elhalil A., Elmoubarki R., Sadiq M., et al. Enhanced photocatalytic degradation of caffeine as a model pharmaceutical pollutant by $\mathrm{Ag}-\mathrm{ZnO}-\mathrm{Al}_{2} \mathrm{O}_{3}$ nanocomposite. Desalination and Water Treatment. 2017;94:254-262.

[51] Kiran VS, Sumathi S. Dielectric studies on Bismuth substituted Zinc aluminate Nanoparticles. ChemTech. Research. 2015;8:097-103.

[52] Iqbal MJ, Farooq S. Effect of doping of divalent and trivalent metal ions on the 
structural and electrical properties of magnesium aluminate. Mater. Sci. Eng., B. 2007;136:140-147.

[53] Iqbal MJ, Kishwar B. Electrical properties of $\mathrm{MgAl}_{2-2 x} \mathrm{Zr}_{\mathrm{x}} \mathrm{M}_{\mathrm{x}} \mathrm{O}_{4}(\mathrm{M}=\mathrm{Co}$, Ni and $\mathrm{x}=0.00-0.20)$ synthesized by co precipitation technique using urea. Mater. Res. Bull. 2008; 44:753-758.

[54] Iqbal MJ, Ismail B, Electric, dielectric and magnetic characteristics of $\mathrm{Cr}^{3+}, \mathrm{Mn}^{3+}$ and $\mathrm{Fe}^{3+}$ substituted $\mathrm{MgAl}_{2} \mathrm{O}_{4}$ : Effect of $\mathrm{pH}$ and annealing temperature. J. Alloys Compd. 2009; 472:434-440.

[55] Iqbal MJ, Ismail B. Correlation between structural and electrical properties of $\mathrm{Mg}_{1-2 \mathrm{x}} \mathrm{Zn}_{\mathrm{x}} \mathrm{Ni}_{\mathrm{x}} \mathrm{Al}_{2} \mathrm{O}_{4}(\mathrm{x}=0.0-0.5)$ ceramic nanomaterials synthesized by a urea assisted microwave combustion method. J. Alloys Compd. 2010; 504:440-445. 
Figures
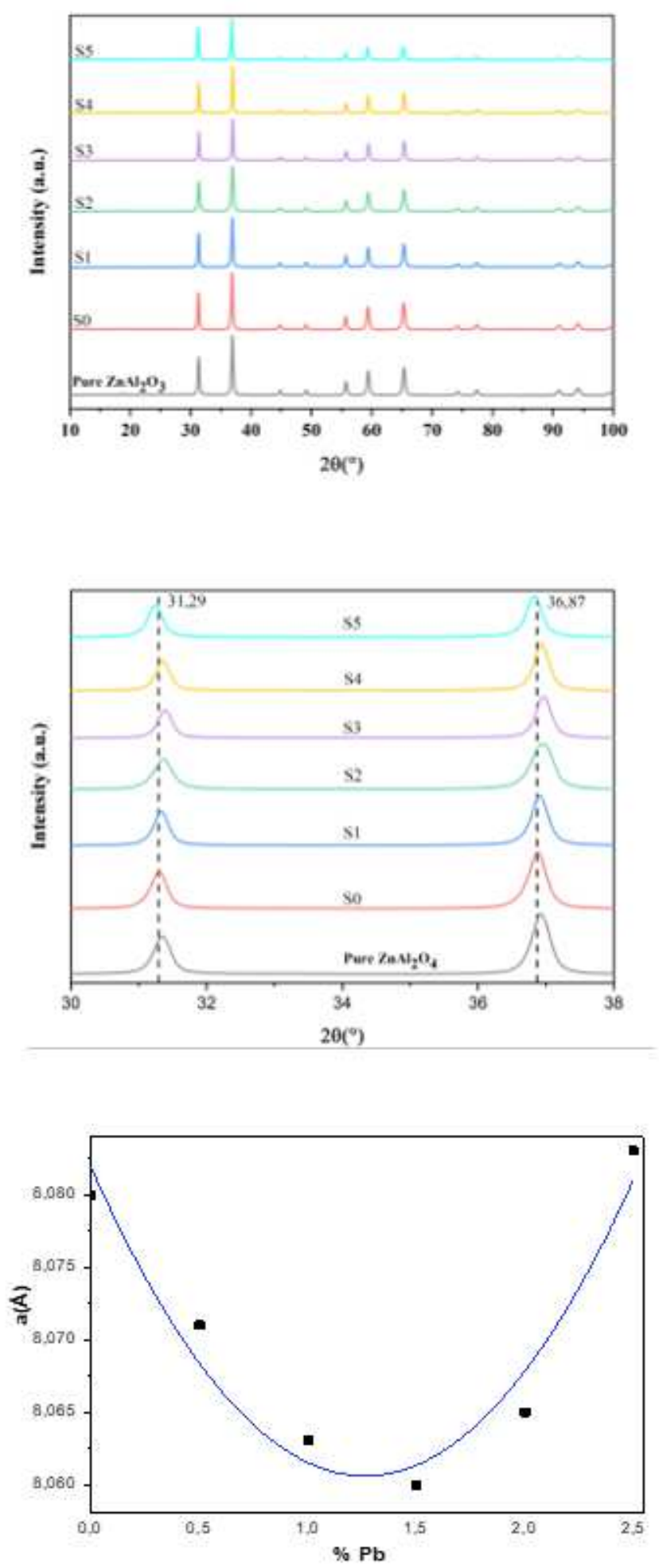

\section{Figure 1}

Fig. 1.a: XRD diagrams of pure ZnAl2O4 and samples S0, S1, S2, S3, S4 and S5. Fig.1.b: Shift of The most intense (220) and (311) diffraction peaks of pure ZnAl204 and Samples S0, S1, S2, S3, S4 and S5. Fig.1.c: The variation of the lattice parameter of the samples versus of the \% $\mathrm{Pb} 2+$. 


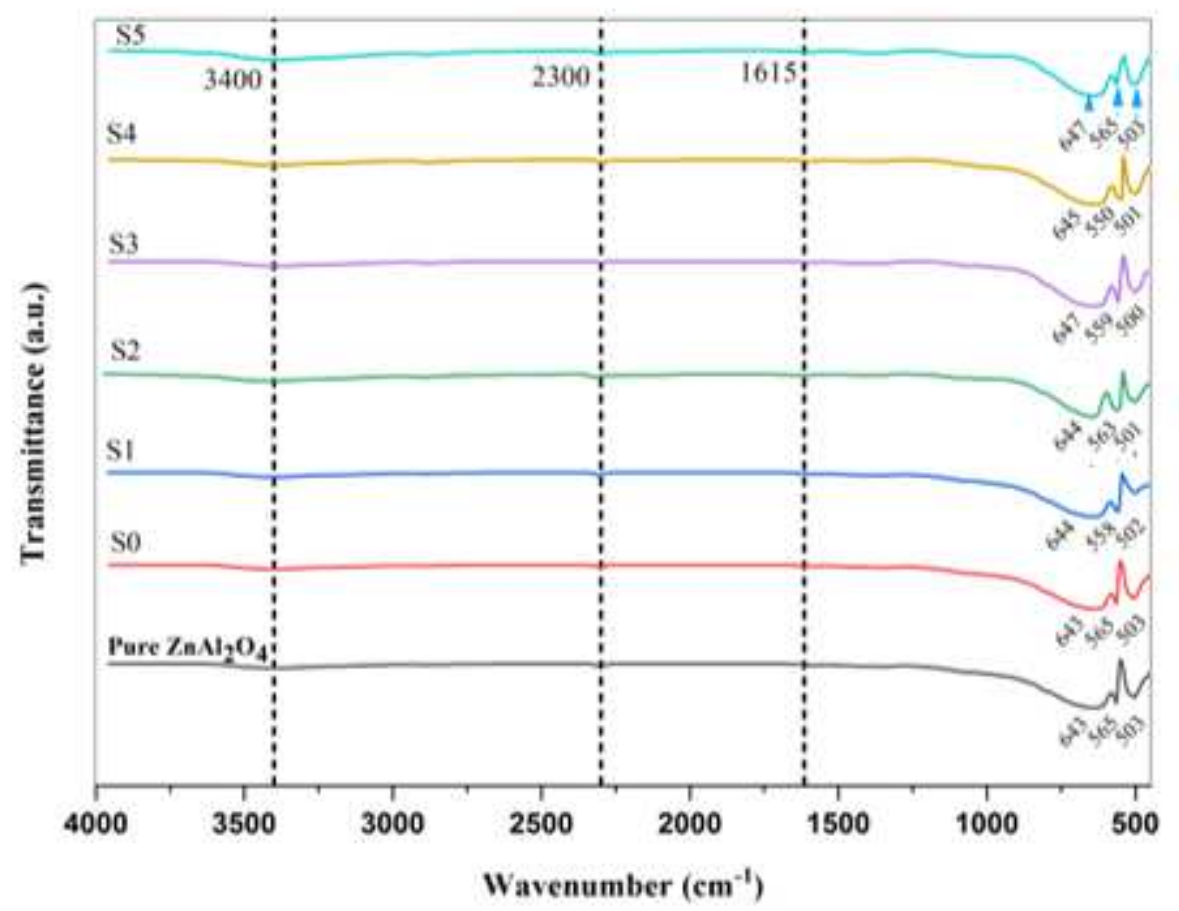

Figure 2

represents the IR spectra of the samples pure ZnAl2O4 and S0, S1, S2, S3, S4 and S5. 

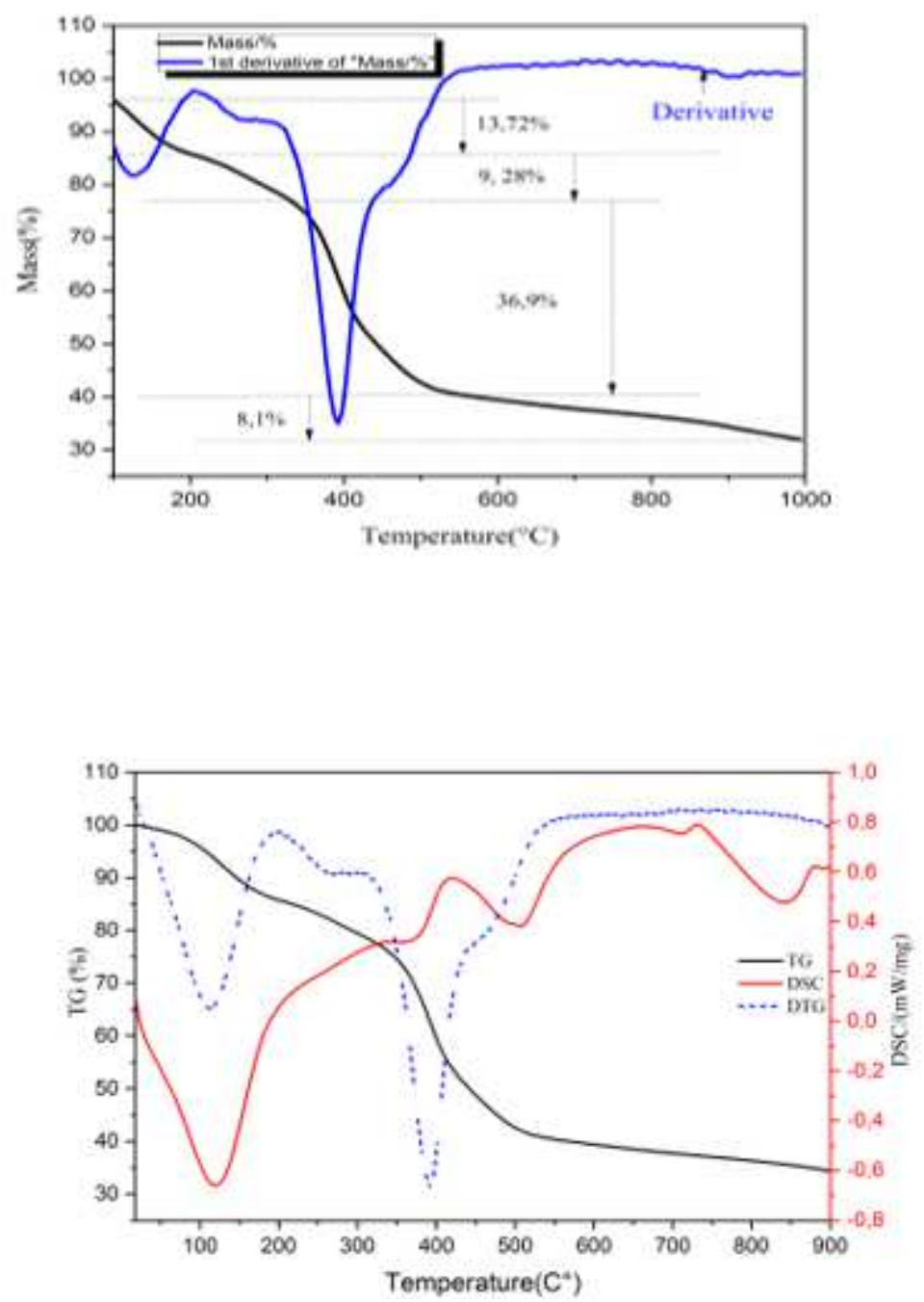

Figure 3

Fig.3.a: DTG of pure ZnAl204. Fig.3.b: DSC of pure ZnAl2O4. 


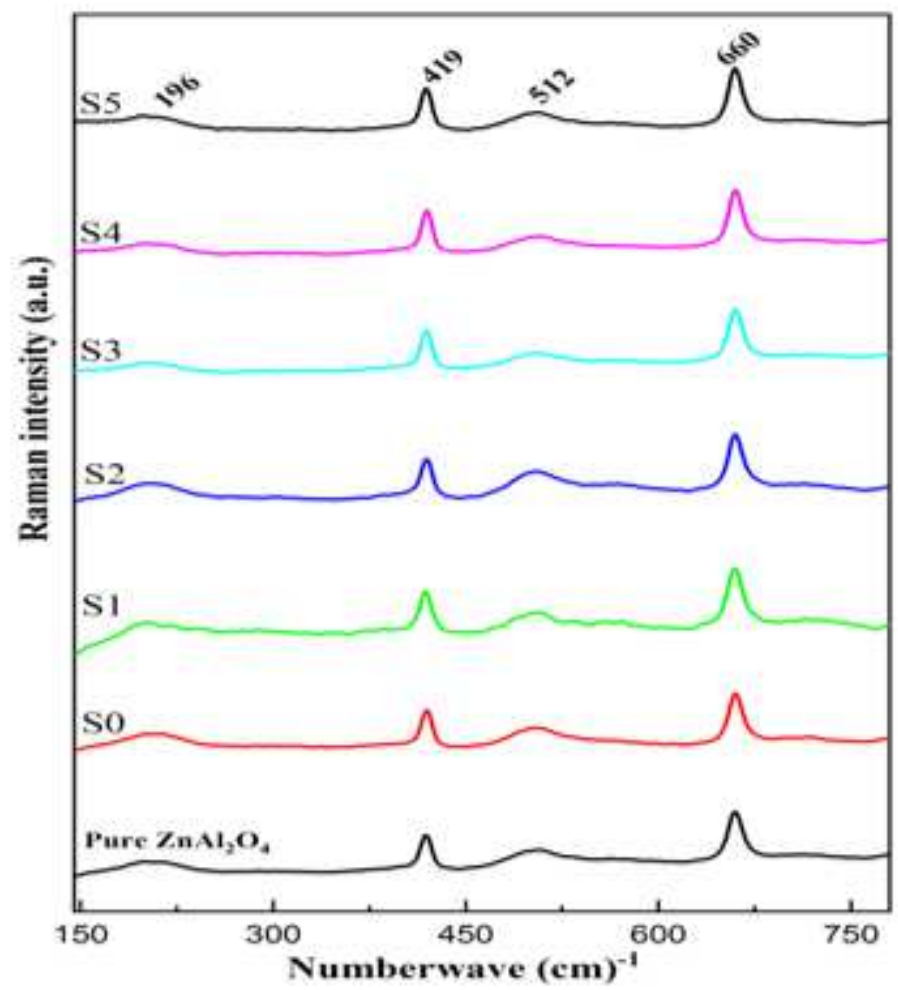

Figure 4

Raman spectra undoped and doped ZnAl2O4 annealed at $900^{\circ} \mathrm{C}$

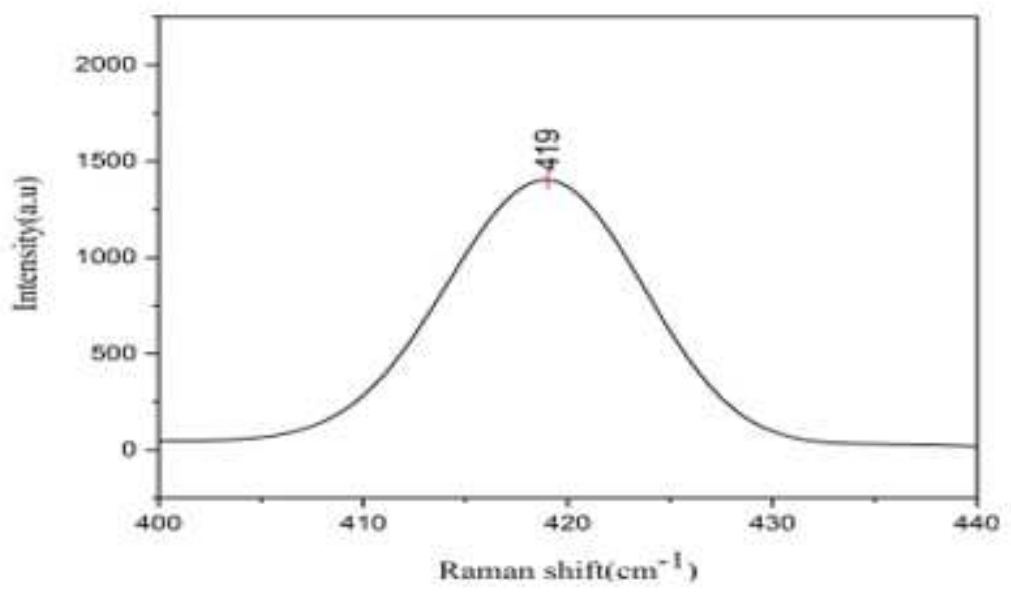

Figure 5

detail of the $419 \mathrm{~cm}-1$ peak, symmetric Gaussian curve fitting, indicating a Negligible asymmetry 


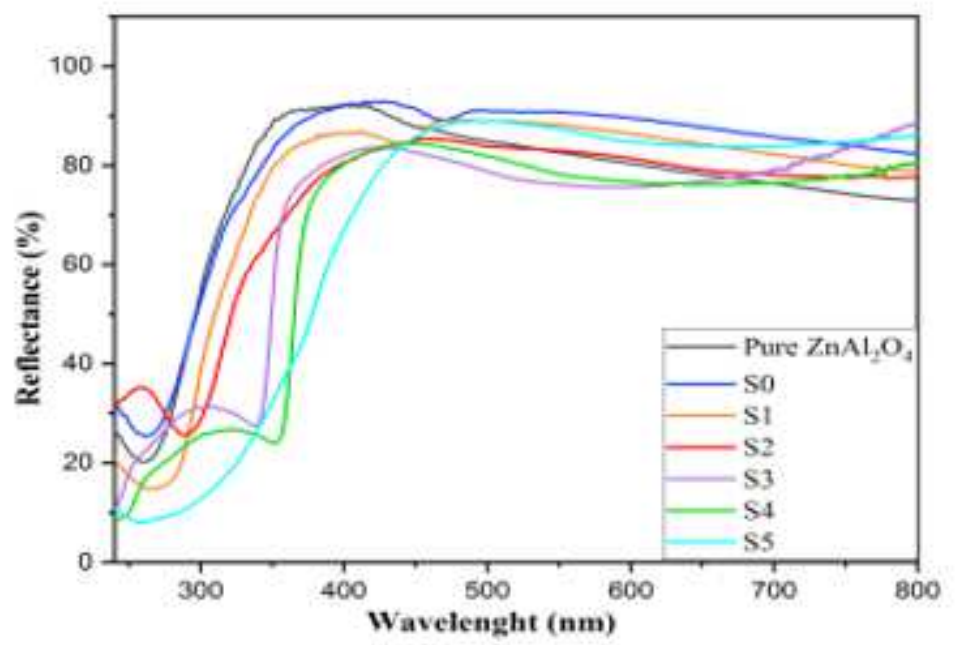

Figure 6

Reflectance of the samples pure ZnAl2O4 and S0, S1, S2, S3, S4 and S5

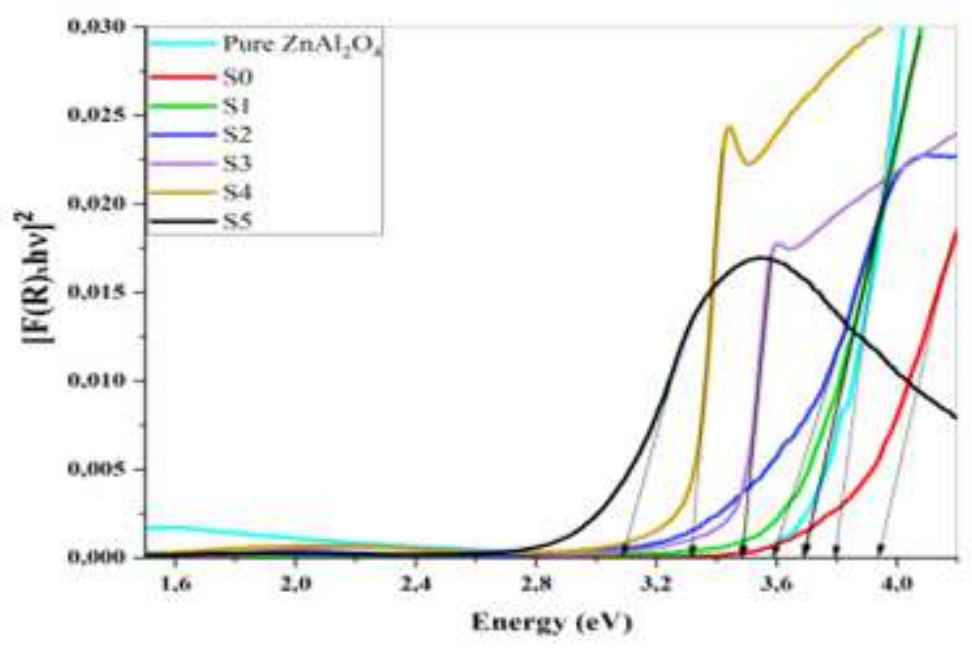

Figure 7

Eg determination 


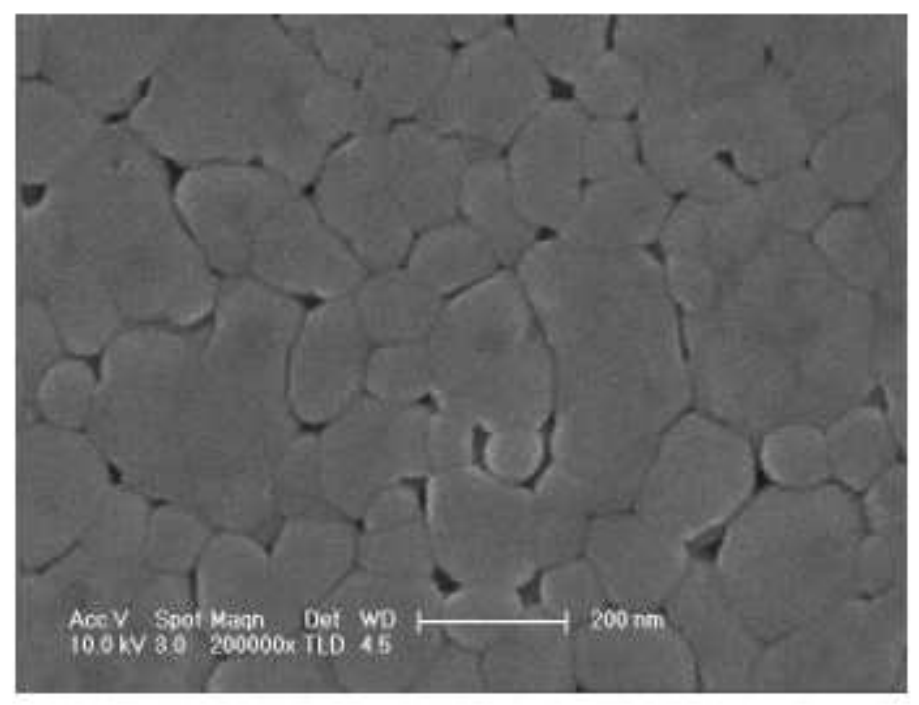

Figure 8

SEM micrographs of ZnAl2O4 nanoparticles synthesized
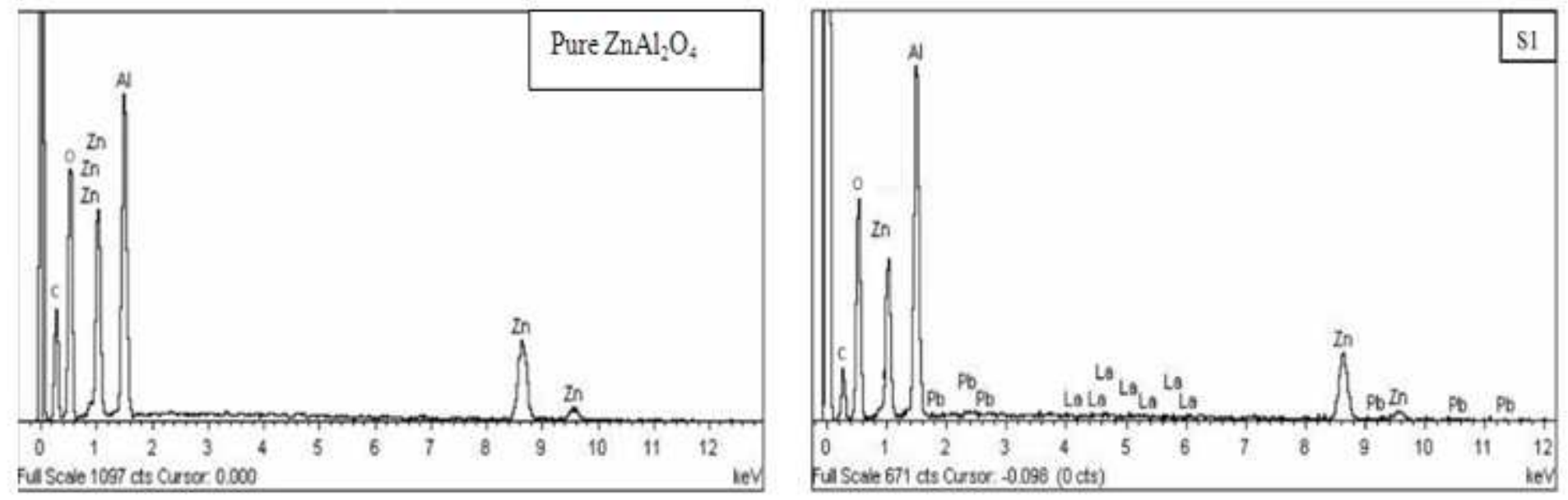

Figure 9

EDX spectra for: a) pure ZnAl2O4 and b) sample S1 


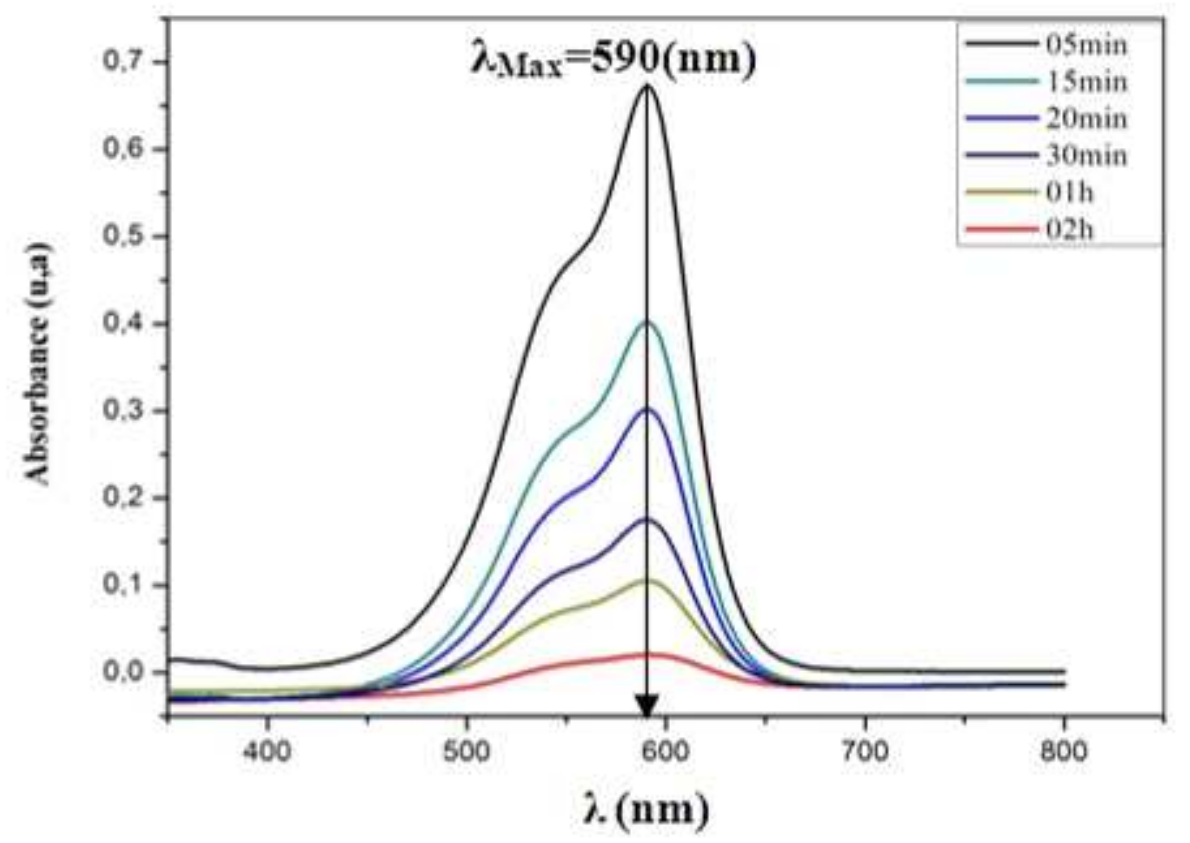

Figure 10

Absorbance of HCV in presence of ZnAl2O4
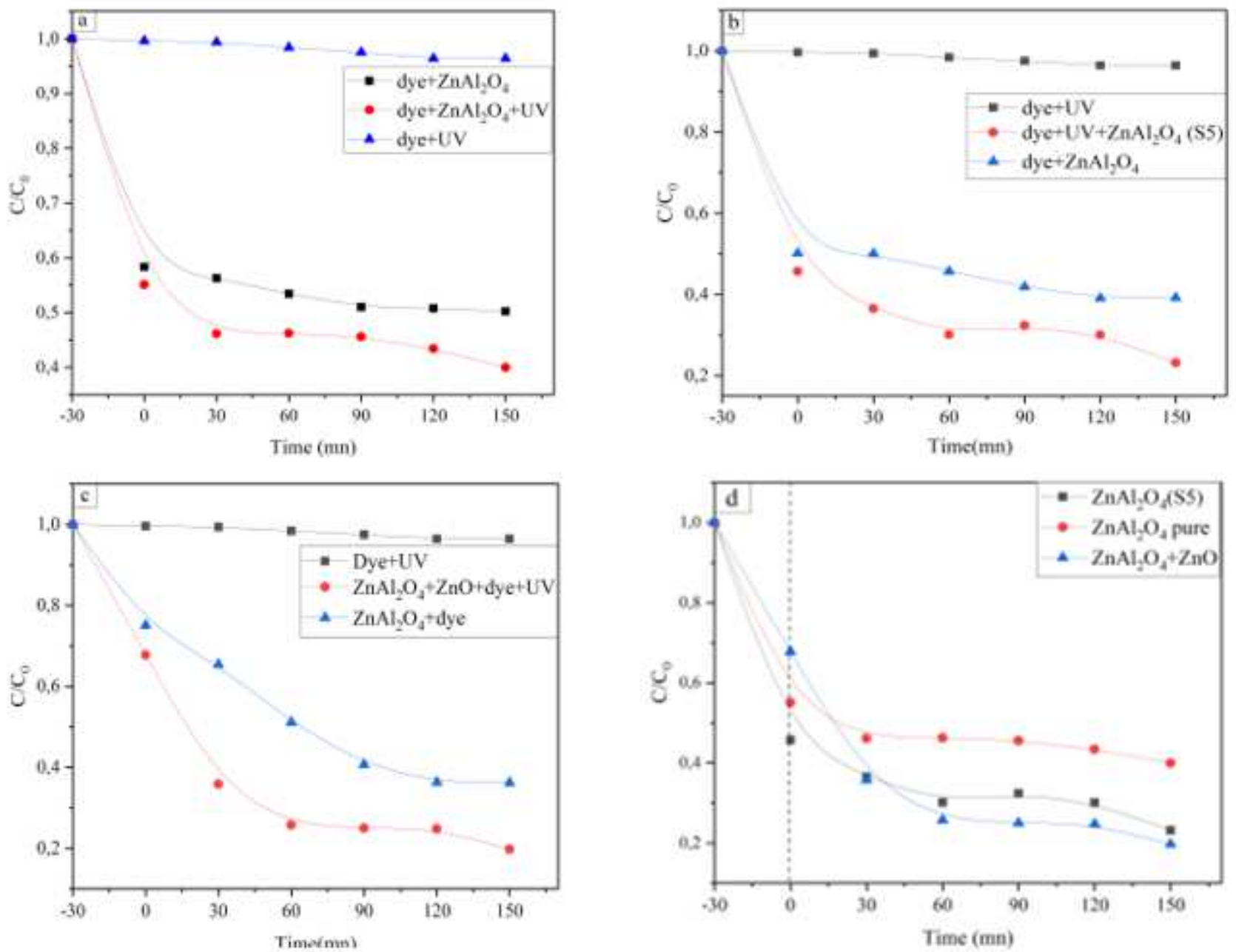
Figure 11

Photocatalytic activity of the ZnAl2O4 pure; ZnAl2O4 (S5) and ZnAl2O4+ZnO 